\title{
EVALUATION OF COMPETITIVENESS OF INDUSTRIES IN REGIONS AND GLOBAL MARKET
}

Astra Auzina-Emsina ${ }^{1}$ Dr.oec.; Velga Ozolina" Dr.oec.

1, 2 Riga Technical University

\begin{abstract}
The paper is devoted to the analysis and evaluation of competitiveness of industries in regions and global market. In the research, one EU economy (Latvia) is examined; however, the methodology and set of indicators can be applied to other EU countries. The aim of the research is to elaborate a set of indicators, in order to evaluate the competitiveness of industries. Productivity and ratio of exports to imports by industries are used to identify the competitiveness of industries in the regions and in global market. The authors argue that that competitiveness of industries in the regions and global market is inhomogeneous and the average national level indicators do not disclose the regional specifics due to the large distribution of indicators' values. The authors argue that the competitiveness of industries in global market are strongly determined by productivity, hence we recommend the policy makers to elaborate programmes that are aimed at potential productivity improvements in industries that are located in the regions and hence use the available EU funds in this financial period as efficiently as possible. Since Latvia is regarded as one region in NUTS 2, the regional development and cohesion is heavily dependent on the national rather than the EU activities.
\end{abstract}

Key words: competitiveness, global market, competitiveness of industries, regions, industries in Latvia.

JEL code: $011,014, \mathrm{R} 11, \mathrm{R} 12$

\section{Introduction}

Evaluation of competitiveness of industries in regions within a country and in the global market is significant due to the fact that the European Union (EU) moves towards the higher competitiveness and stronger economies. In the current financial period (in 2014-2020 period), one of the major EU policies, Cohesion policy, is focused strongly on supporting smart growth with particular emphasis on innovation and high growth companies and includes policy programmes aimed at increasing the innovative capacity of small and medium-sized enterprises (SMEs) (European Commission, 2017). The European Commission estimates that for the current financial period, for example, Cohesion policy will support 1.1 million SMEs (European Commission, 2017). SME as a legal object is strictly defined by Commission Recommendation (European Commission, 2003).

It should be stressed that in the EU, the regions eligible for support from Regional or Cohesion policy have been defined at NUTS 2 level and hence the Cohesion report has so far mainly been prepared at NUTS 2 level. But in several countries (including Latvia) there is only one region according to NUTS 2 level and hence the national government institutions, non-governmental organisations (NGOs), research, academic etc. institutions have limited options to evaluate the actual situation regarding regional economic and social development and take effective actions. The hypothesis of this research is: competitiveness of industries in the regions and global market is inhomogeneous and the average national level indicators do not disclose the regional specifics.

The aim of the research is to analyse and evaluate the competitiveness of industries in Latvia's regions and global market in the framework of limited statistical data. The tasks of the research: 1) review of previous studies, researches, reports, policy documents; 2) elaboration of set of indicators; 3) collection and analysis of available statistical data in NUTS 3 level; 4) elaboration of recommendations to policy makers etc. In the research, the main focus is on one EU country Latvia; however, the methods and practical findings are topical to and can be applied in many EU member countries as well the potential EU member countries, taking into account the size of the 
country and the economy and regional breakdown of a country according to NUTS 2 . In the research, quantitative and qualitative research methods are applied.

The research period is from 2010 to 2016 (or to the latest data available). The statistical analysis within the research mainly focussed on Latvia; however, the data on the other EU countries or the EU can be integrated if demanded. Annual data provided by the Central Statistical Bureau (CSB) of Latvia (Central Statistical Bureau of Latvia, 2018) are used in the research.

\section{Literature review}

The concept of competitiveness and understanding of this concept have gradually changed. In the late 1990s, the researches stressed the dynamic component of competitiveness. For example, Swedish researchers argued that the changes in the international economy have gradually shifted the basis of industrial competitiveness from static price competition towards dynamic improvement (Maskell \& Malmberg, 1999). These authors also use an additional concept - sustainable competitiveness, and they argue that it requires the ongoing replacement of decrepit resources (Maskell \& Malmberg, 1999). Nowadays, majority of authors accept that competitiveness is dynamic and competitiveness should be analysed and compared in different countries and different time periods as competitiveness indirectly demands comparison. Something can be more competitive only if compared to something else.

But it should be stressed that if the competitiveness cannot be measured, it cannot be improved (Bruneckiene, Guzavicius, \& Cincikaite, 2010). Hence, the evaluation of competitiveness is so important for many involved agents in the economy.

Rural development and developed regions within the EU are some of the EU targets hence Cohesion policy is an important part of the EU economic policies. As the regions eligible for support from Cohesion policy have been defined at NUTS 2 level, the Cohesion report (European Commission, 2017) representing the policy performance has so far mainly been prepared at NUTS 2 level.

The geographical map of the EU Structural Funds (ERDF and ESF) eligibility 2014-2020 illustrates the regions according to NUTS 2 level and corresponding level of development (as indicator is applied a gross domestic product per inhabitant (as \% of EU-27 average) (European Commission, 2017)). All the regions for the policy are subdivided by the European Commission (European Commission, 2017) into 3 major groups: less developed regions, transition regions and more developed regions.

Hence it is significant to review the current studies in the field. The review of latest studies in competitiveness in the EU countries shows that the concept of competitiveness is widely applied and the concept is being extended and new meanings and features included. European Commission (European Commission, 2017) evaluates regional competitiveness by Regional Competitiveness Index (RCI) that is designed to capture the different dimensions of competitiveness for NUTS 2 regions summarized in eleven pillars (Annoni \& Dijkstra, 2010). European Commission argues that $\mathrm{RCI}$ is the first measure to provide an EU wide perspective on this (European Commission, 2017). But, for example, the urban performance evaluation includes urban competitiveness, that is linked to concept of smart cities (Caragliu, Del Bo, \& Nijkamp, 2011). Urban competitiveness in Lithuania is measured and evaluated by index - urban competitiveness index (Bruneckiene, Guzavicius, \& Cincikaite, 2010). 
Competitiveness is also analysed in the context of the EU funding. The Lithuanian researchers argue that change in EU funding was found to have statistically significant impact on competitiveness level of certain industries (tourism and agriculture sectors) (Balzaraviciene \& Pilinkiene, 2012). It was also determined that EU structural funds have significant influence on infrastructure and macroeconomic, scientific and social environment (Remeikiene \& Gaspareniene, 2016). Research in the Czech Republic showed that only European Social Fund has helped to increase productivity (Martinez \& Potluka, 2015). The authors that researched the export competitiveness and productivity in Lithuania, argue that the export competitiveness is a derivative of main factors' productivities (Travkina \& Tvaronaviciene, 2011). Another report on the EU funds concludes that these have helped to enhance competitiveness of regions in Romania and Bulgaria (Gabriela \& Delia, 2015).

Regarding the methods, the competitiveness of Polish companies in global market and the perspective of Poland joining the euro zone are examined on the basis of the analysed sample of companies (Dzikowska, Gorynia, Jankowska, \& Pietrzykowski, 2014). Research of the EU-wide competitiveness issues uses panel data regression and reveals that the influence of the EU Structural and Cohesion funds on competitiveness is positive in the long run (Tijanic \& Obadic, 2015).

Literature on export competitiveness is researched in several EU countries (including Latvia) and applied methods, scale, geographical coverage vary. Export competitiveness of the Baltic States is measured by Composite Index (Bruneckiene \& Paltanaviciene, 2012). At the same time, some authors analyse export competitiveness of certain industry or group of products (as (Bojnec \& Ferto, 2014) analysed the export competitiveness of the EU of dairy products in global markets using revealed comparative advantage (RCA) index). Some authors examine certain sector of the national economy and its impact on the competitiveness of the country or region (as (Maciulis, Vasiliauskas, \& Jakubauskas, 2009) researched the impact of transport on national economy (Lithuania) and its competitiveness, applying the selected indicators: the share of transport in the national (Lithuania's) GDP ( \%) and the ratio of the export of transport services to national GDP $(\%)$ ). In order to identify factors determining industrial competitiveness, the author (Kleynhans, 2016) has used the data from the Manufacturing Firm Survey of the World Bank and applied regressions and panel data analysis.

A huge variety of methods and approaches are used to analyse and evaluate the competitiveness that include both complex and simple methods. Competitiveness is a complex concept and hence we can conclude that the choice of method applied is strongly determined by the objectives and aim, size and other specifics of the research.

\section{Methods and methodology}

The authors have elaborated methodology, which includes the steps:

- analyse industries on national scale;

- analyse regional structure;

- select and analyse the selected industries that are allocated in regions;

- evaluate and conclude on competitiveness of selected industries.

Set of indicators selected and applied in the research are:

- value added by industries (NACE Rev. 2) - sectoral structure; dynamics; 
- value added by industries(NACE Rev. 2) and by planning regions (NUTS 3) - regional sectoral structure; dynamics;

- productivity by industries (NACE Rev. 2) (see Formulae 1)- comparison and dynamics of selected industries;

- competitiveness of industries in open market as ratio of exports to imports by industries (NACE Rev. 2) (see Formulae 2) - comparison and dynamics of selected industries.

The authors propose to analyse productivity as a ratio of the value added to output (Formulae 1). This indicator $r_{-}$prodi,t illustrates the share of added value in output value; the indicator $r_{-}$prodi, $t$ by its sense is direct cost coefficient in context of input-output analysis. The computed values of $r_{-}$prodi, $t$ are comparable in one time period (one industry to other industries; national level or international comparisons (static analysis)) and also in dynamics comparison (one industry in certain time period (comparable-dynamic analysis)).

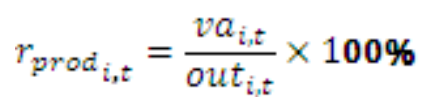

Where:

$r i, t$ - ratio of value added to output by industries i (NACE Rev. 2) in time period t;

vai, $t$ - value added of industries i in time period $t$ (at current prices; data source CSB);

outi, $t$ - output of industries i in time period $t$ (at current prices; data source CSB).

Formulae 2 is used to compute the competitiveness of industries in open market. The computed values of $r_{-} c i, t$ (like $r_{-}$prodi,t values) are comparable in one time period (both national and international comparison (static analysis)) and also in dynamics comparison (comparable-dynamic analysis).

$$
r_{\mathrm{c}_{i, t}}=\frac{\exp _{i, t}}{i m p_{i, t}} \times 100 \%
$$

Where:

$r_{-} c i, t$ - ratio of exports to imports by industries i (NACE Rev. 2) in time period t;

expi, $t$ - exports of goods of industries $i$ in time period $t$ (at current prices; data source CSB);

impi, $t$ - imports of goods of industries $i$ in time period $t$ (at current prices; data source CSB).

The content of set of indicators listed above is determined strongly by availability of detailed statistical data. Unfortunately, in respect to analysis and modelling of regional productivity and competitiveness of industries, many significant aspects and dimensions are not covered by CSB data. Due to these limitations, the research is strongly based on national accounts data.

\section{Analysis of statistical data and discussion}

The economy of Latvia grows and the total gross value added accounted for 21.7 billion euros in 2016. The set of leading industries in respect to the share in the economy is stable (according to NACE Rev. 2) - wholesale and retail trade (3.2 billion euros or $14.7 \%$ of total value added in 2016); real estate activities (2.7 billion euros or $12.4 \%$ ); manufacturing ( 2.7 billion euros or $12.3 \%)$; transportation and storage (1.9 billion euros or $8.7 \%$ ); public administration and defence, compulsory social security ( 1.7 billion euros or $7.6 \%)$. These five above mentioned industries formed $55.7 \%$ of total economy (in money terms - they created value added of 12.1 billion euros). Then follows the construction with its growing endowment and stable share in the economy ( 1.1 billion euros or $5.3 \%$ ). 
However, the statistical analysis taking into account regional allocation reveals that the leading industries are mainly located in Riga region (Table 1 ), that accounted for $54 \%$ of total value added in 2015 (it should be outlined that in CSB data base there are no sectoral data of total value added in cities (except Riga) by kind of economic activity and CSB (Central Statistical Bureau of Latvia, 2018) admits that the data are not available or are too uncertain for presentation). The industries that are allocated more evenly are primary and secondary sectors - agriculture, mining, and manufacturing. Services or tertiary sector's economic activities (with some exceptions regarding public services (as education, human health and social work activities etc.) are dominantly located in cities and by large extent in Riga region. The authors argue that the service industries that are directly linked to population in regions and primary and secondary industries due to the allocation of resources and production traditions are allocated in regions more evenly.

Table 1

Share of total value added in statistical regions by kind of economic activity (NACE Rev. 2) in Latvia in 2015 ( \%)

\begin{tabular}{|c|c|c|c|c|c|c|}
\hline $\begin{array}{l}\text { Industry or economic activity } \\
\text { (NACE Rev. } 2 \text { code) }\end{array}$ & $\begin{array}{l}\text { Riga } \\
\text { region }\end{array}$ & $\begin{array}{l}\text { Pieriga } \\
\text { region }\end{array}$ & $\begin{array}{l}\text { Vidzeme } \\
\text { region }\end{array}$ & $\begin{array}{l}\text { Kurzeme } \\
\text { region }\end{array}$ & $\begin{array}{l}\text { Zemgale } \\
\text { region }\end{array}$ & $\begin{array}{l}\text { Latgale } \\
\text { region }\end{array}$ \\
\hline $\begin{array}{l}\text { (A) Agriculture, Forestry and } \\
\text { Fishing }\end{array}$ & $8 \%$ & $14 \%$ & $23 \%$ & $18 \%$ & $25 \%$ & $12 \%$ \\
\hline (B) Mining and quarrying & $1 \%$ & $24 \%$ & $18 \%$ & $24 \%$ & $24 \%$ & $9 \%$ \\
\hline (C) Manufacturing & $35 \%$ & $22 \%$ & $10 \%$ & $13 \%$ & $12 \%$ & $9 \%$ \\
\hline $\begin{array}{l}\text { (D) Electricity, gas, steam and air } \\
\text { conditioning supply }\end{array}$ & $48 \%$ & $17 \%$ & $8 \%$ & $9 \%$ & $11 \%$ & $6 \%$ \\
\hline (E) Water supply, sewerage etc. & $29 \%$ & $28 \%$ & $7 \%$ & $12 \%$ & $13 \%$ & $11 \%$ \\
\hline (F) Construction & $59 \%$ & $13 \%$ & $6 \%$ & $9 \%$ & $7 \%$ & $5 \%$ \\
\hline (G) Wholesale and retail trade etc. & $62 \%$ & $14 \%$ & $5 \%$ & $7 \%$ & $6 \%$ & $6 \%$ \\
\hline (H) Transportation and storage & $51 \%$ & $18 \%$ & $2 \%$ & $14 \%$ & $5 \%$ & $10 \%$ \\
\hline $\begin{array}{l}\text { (I) Accommodation and food } \\
\text { service activities }\end{array}$ & $69 \%$ & $15 \%$ & $4 \%$ & $6 \%$ & $4 \%$ & $3 \%$ \\
\hline $\begin{array}{l}\text { (J) Information and } \\
\text { communication }\end{array}$ & $84 \%$ & $6 \%$ & $2 \%$ & $4 \%$ & $1 \%$ & $3 \%$ \\
\hline $\begin{array}{l}\text { (K) Financial and insurance } \\
\text { activities }\end{array}$ & $85 \%$ & $6 \%$ & $2 \%$ & $3 \%$ & $2 \%$ & $2 \%$ \\
\hline (L) Real estate activities & $48 \%$ & $20 \%$ & $7 \%$ & $11 \%$ & $7 \%$ & $8 \%$ \\
\hline $\begin{array}{l}\text { (M) Professional, scientific and } \\
\text { technical activities }\end{array}$ & $79 \%$ & $9 \%$ & $2 \%$ & $4 \%$ & $3 \%$ & $2 \%$ \\
\hline $\begin{array}{l}\text { (N) Administrative and support } \\
\text { service activities }\end{array}$ & $67 \%$ & $14 \%$ & $4 \%$ & $6 \%$ & $4 \%$ & $5 \%$ \\
\hline $\begin{array}{l}\text { (O) Public administration and } \\
\text { defence; compulsory social } \\
\text { security }\end{array}$ & $56 \%$ & $9 \%$ & $6 \%$ & $9 \%$ & $7 \%$ & $10 \%$ \\
\hline (P) Education & $42 \%$ & $15 \%$ & $9 \%$ & $11 \%$ & $10 \%$ & $13 \%$ \\
\hline $\begin{array}{l}\text { (Q) Human health and social work } \\
\text { activities }\end{array}$ & $54 \%$ & $10 \%$ & $7 \%$ & $10 \%$ & $8 \%$ & $10 \%$ \\
\hline $\begin{array}{l}(R) \text { Arts, entertainment and } \\
\text { recreation }\end{array}$ & $56 \%$ & $16 \%$ & $6 \%$ & $9 \%$ & $7 \%$ & $7 \%$ \\
\hline$(S, T)$ Other service activities etc. & $61 \%$ & $14 \%$ & $5 \%$ & $7 \%$ & $6 \%$ & $6 \%$ \\
\hline Total & $54 \%$ & $15 \%$ & $7 \%$ & $9 \%$ & $8 \%$ & $7 \%$ \\
\hline
\end{tabular}

In the research, productivity of industries is evaluated by the computed ratio of value added to output. Figure 1 shows the dynamics of productivity in Latvia in 2010-2016. 


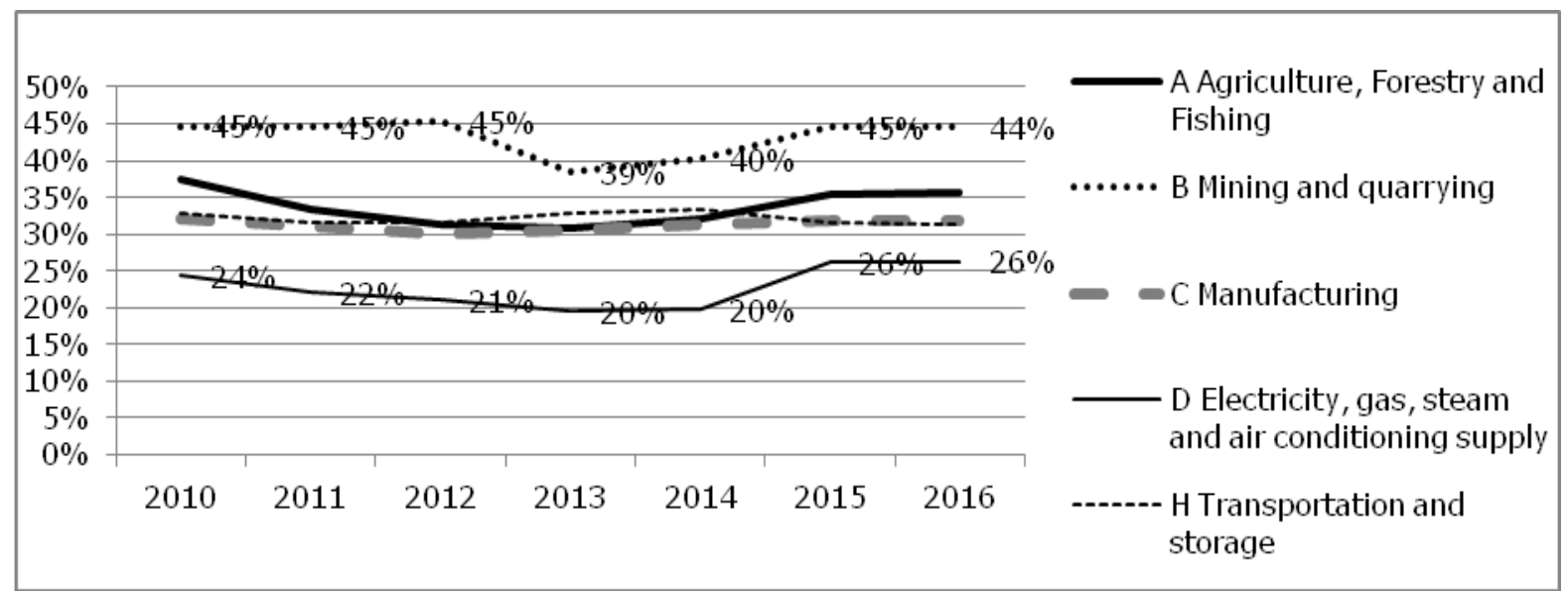

Source: authors' calculations based on CSB data

Fig. 1. Ratio of value added to output by selected industries in Latvia in 2010-2016 (\%)

In Latvia, the primary sector activities, such as mining, have the highest productivity amid the compared industries that is uncommon trend. On average, the ratio was $46 \%$ in Latvia in 2016 as the service sector dominates and services mainly have higher productivity. Productivity of agriculture and manufacturing (sectors that are also located in regions and rural areas) are below the average level that leads to the situation that regions are less developed, have fewer resources, face emigration to larger cities or abroad etc.

In order to evaluate the competitiveness of industries in the global market, exports and imports of the industries are analysed (Table 2).

The evaluation results of the computed ratios of exports and imports of goods by industries give the basis to argue that the industries or economic activities that are allocated more evenly in Latvia have higher values of this ratio. Moreover, relatively higher values are in those industries, which are more traditional in Latvia like forestry and logging, fishing and agriculture and other mining and quarrying. Values of ratio of exports to imports are comparatively high also in manufacturing of pharmaceutical products, which is a high-tech industry mainly located in Riga and Riga region. These industries can be considered as highly competitive.

For other industries, two options are possible. There are industries like crop and animal production and manufacturing of food, which relies heavily on domestic demand. Some others like manufacture of paper products, manufacture of computer etc. products and manufacture of motor vehicles use imported products for export as well, thus showing competitiveness in transit field.

Significant decrease of this ratio shows that the local resources are becoming scarce and need to be imported. Increase of this ratio might indicate that a particular industry is becoming more competitive globally, or is able to substitute imports due to larger global competitiveness in domestic market or both. 
Ratio of exports to imports in agriculture, mining and manufacturing

Table 2 industries (NACE Rev. 2) in Latvia in 2010-2016

\begin{tabular}{|c|c|c|c|c|c|c|c|c|}
\hline $\begin{array}{l}\text { NACE } \\
\text { code }\end{array}$ & Industry & 2010 & 2011 & 2012 & 2013 & 2014 & 2015 & 2016 \\
\hline TOTAL & Total & $79 \%$ & $78 \%$ & $79 \%$ & $79 \%$ & $81 \%$ & $83 \%$ & $85 \%$ \\
\hline A01 & $\begin{array}{l}\text { Crop and animal production, } \\
\text { hunting and related service } \\
\text { activities }\end{array}$ & $111 \%$ & $81 \%$ & $120 \%$ & $135 \%$ & $131 \%$ & $151 \%$ & $146 \%$ \\
\hline A02 & Forestry and logging & $1533 \%$ & $1175 \%$ & $955 \%$ & $1448 \%$ & $1276 \%$ & $688 \%$ & $556 \%$ \\
\hline A03 & Fishing and aquaculture & $579 \%$ & $306 \%$ & $253 \%$ & $348 \%$ & $387 \%$ & $409 \%$ & $698 \%$ \\
\hline B08 & Other mining and quarrying & $497 \%$ & $367 \%$ & $382 \%$ & $391 \%$ & $401 \%$ & $436 \%$ & $501 \%$ \\
\hline C10 & Manufacture of food products & $144 \%$ & $143 \%$ & $137 \%$ & $157 \%$ & $155 \%$ & $142 \%$ & $136 \%$ \\
\hline C11 & Manufacture of beverages & $87 \%$ & $73 \%$ & $71 \%$ & $105 \%$ & $89 \%$ & $86 \%$ & $82 \%$ \\
\hline C13 & Manufacture of textiles & $166 \%$ & $160 \%$ & $160 \%$ & $165 \%$ & $167 \%$ & $151 \%$ & $152 \%$ \\
\hline C14 & Manufacture of wearing apparel & $147 \%$ & $175 \%$ & $163 \%$ & $161 \%$ & $167 \%$ & $174 \%$ & $180 \%$ \\
\hline C15 & $\begin{array}{l}\text { Manufacture of leather and } \\
\text { related products }\end{array}$ & $229 \%$ & $192 \%$ & $200 \%$ & $199 \%$ & $167 \%$ & $180 \%$ & $154 \%$ \\
\hline C16 & $\begin{array}{l}\text { Manufacture of wood and of } \\
\text { products of wood and cork, } \\
\text { except furniture; manufacture of } \\
\text { articles of straw and plaiting } \\
\text { materials }\end{array}$ & $702 \%$ & $597 \%$ & $576 \%$ & $522 \%$ & $455 \%$ & $474 \%$ & $456 \%$ \\
\hline C17 & $\begin{array}{l}\text { Manufacture of paper and paper } \\
\text { products }\end{array}$ & $120 \%$ & $115 \%$ & $129 \%$ & $101 \%$ & $98 \%$ & $116 \%$ & $108 \%$ \\
\hline C18 & $\begin{array}{l}\text { Printing and reproduction of } \\
\text { recorded media }\end{array}$ & $173 \%$ & $205 \%$ & $213 \%$ & $217 \%$ & $229 \%$ & $172 \%$ & $238 \%$ \\
\hline C20 & $\begin{array}{l}\text { Manufacture of chemicals and } \\
\text { chemical products }\end{array}$ & $127 \%$ & $120 \%$ & $110 \%$ & $161 \%$ & $164 \%$ & $173 \%$ & $213 \%$ \\
\hline C21 & $\begin{array}{l}\text { Manufacture of basic } \\
\text { pharmaceutical products and } \\
\text { pharmaceutical preparations }\end{array}$ & $683 \%$ & $455 \%$ & $482 \%$ & $400 \%$ & $411 \%$ & $379 \%$ & $453 \%$ \\
\hline C22 & $\begin{array}{l}\text { Manufacture of rubber and } \\
\text { plastic products }\end{array}$ & $111 \%$ & $107 \%$ & $95 \%$ & $91 \%$ & $110 \%$ & $104 \%$ & $108 \%$ \\
\hline C23 & $\begin{array}{l}\text { Manufacture of other non- } \\
\text { metallic mineral products }\end{array}$ & $216 \%$ & $203 \%$ & $237 \%$ & $233 \%$ & $205 \%$ & $188 \%$ & $223 \%$ \\
\hline C24 & Manufacture of basic metals & $172 \%$ & $134 \%$ & $188 \%$ & $280 \%$ & $130 \%$ & $115 \%$ & $148 \%$ \\
\hline C25 & $\begin{array}{l}\text { Manufacture of fabricated metal } \\
\text { products, except machinery and } \\
\text { equipment }\end{array}$ & $180 \%$ & $180 \%$ & $178 \%$ & $201 \%$ & $186 \%$ & $201 \%$ & $255 \%$ \\
\hline C26 & $\begin{array}{l}\text { Manufacture of computer, } \\
\text { electronic and optical products }\end{array}$ & $159 \%$ & $170 \%$ & $208 \%$ & $149 \%$ & $190 \%$ & $153 \%$ & $153 \%$ \\
\hline C27 & $\begin{array}{l}\text { Manufacture of electrical } \\
\text { equipment }\end{array}$ & $165 \%$ & $177 \%$ & $159 \%$ & $166 \%$ & $185 \%$ & $157 \%$ & $156 \%$ \\
\hline C28 & $\begin{array}{l}\text { Manufacture of machinery and } \\
\text { equipment n.e.c. }\end{array}$ & $315 \%$ & $249 \%$ & $216 \%$ & $223 \%$ & $225 \%$ & $266 \%$ & $255 \%$ \\
\hline C29 & $\begin{array}{l}\text { Manufacture of motor vehicles, } \\
\text { trailers and semi-trailers }\end{array}$ & $180 \%$ & $186 \%$ & $193 \%$ & $218 \%$ & $243 \%$ & $206 \%$ & $235 \%$ \\
\hline C30 & $\begin{array}{l}\text { Manufacture of other transport } \\
\text { equipment }\end{array}$ & $113 \%$ & $83 \%$ & $136 \%$ & $264 \%$ & $127 \%$ & $121 \%$ & $505 \%$ \\
\hline C31 & Manufacture of furniture & $297 \%$ & $277 \%$ & $271 \%$ & $264 \%$ & $220 \%$ & $259 \%$ & $274 \%$ \\
\hline C32 & Other manufacturing & $183 \%$ & $227 \%$ & $217 \%$ & $301 \%$ & $274 \%$ & $303 \%$ & $245 \%$ \\
\hline C33 & $\begin{array}{l}\text { Repair and installation of } \\
\text { machinery and equipment }\end{array}$ & $36 \%$ & $28 \%$ & $39 \%$ & $41 \%$ & $64 \%$ & $26 \%$ & $35 \%$ \\
\hline
\end{tabular}

Source: authors' calculations based on CSB data 


\section{Conclusions and recommendations}

1) The set hypothesis is approved that competitiveness of industries in regions and global market is inhomogeneous and the average national level indicators do not disclose the regional specifics.

2) Industries are unevenly located in the territory of Latvia and those industries that are located in other regions (not in Riga region) show lower productivity level that influences the competitiveness of the region and industries.

3) As Latvia is a single region in NUTS 2 classification, then the regional development and cohesion is heavily dependent on the national rather than the EU activities.

4) The authors strongly recommend to collect and publish more disaggregated data on economic activities in the regions by the CSB, in order to have comparable and reliable basis of data for more detailed studies (for example, value added, output, employment by industries (NACE Rev. 2 Level 2 (in 88 divisions)) in regions (at least 6 planning regions).

5) The authors recommend the ministries and other government institutions (including the municipalities) to monitor the economic activity in the regions, since the average or total figures of major indicators do not represent the situation in the regions.

6) Competitiveness of industries in global market are strongly determined by productivity, hence the authors recommend the policy makers to elaborate programmes that are aimed at potential productivity improvements in industries that are located in the regions and use the available EU funds in this financial period (2014-2020) as efficiently as possible.

\section{Acknowledgements}

The paper was supported by the National Research Program 5.2. "Economic Transformation, Smart Growth, Governance and Legal Framework for the State and Society for Sustainable Development - a New Approach to the Creation of a Sustainable Learning Community (EKOSOC-LV)"

\section{Bibliography}

1. Annoni, P. , \& Dijkstra, L. (2010). EU Regional Competitiveness Index. Luxemburg: European Commission.

2. Balzaraviciene, S., \& Pilinkiene, V. (2012). Evaluation of Competitiveness of Lithuanian Economic Sectors Using Competitiveness Indices: Impact of European Union Funding. Transformations in Business and Economics, 11(2), 98-116.

3. Bojnec, S., \& Ferto, I. (2014). Export Competitiveness Of Dairy Products On Global Markets: The Case Of The European Union Countries. Journal of Dairy Science, 97(10), 6151-6163.

4. Bruneckiene, J., \& Paltanaviciene, D. (2012). Measurement of Export Competitiveness of the Baltic States by Composite Index. Inzinerine Ekonomika-Engineering Economics, 23(1), 50-62.

5. Bruneckiene, J., Guzavicius, A., \& Cincikaite, R. (2010). Measurement Of Urban Competitiveness In Lithuania. Engineering Economics, 21(5), 493-508.

6. Caragliu, A., Del Bo, C., \& Nijkamp, P. (2011). Smart Cities in Europe. Journal of Urban Technology, 18(2), 65-82.

7. Central Statistical Bureau of Latvia. (2018). Statistics Database. Riga: Central Statistical Bureau of Latvia. Retrieved: http://www.csb.gov.lv/en/dati/statistics-database-30501.html. Access: 02.02.2018.

8. Dzikowska, M., Gorynia, M., Jankowska, B., \& Pietrzykowski, M. (2014). International Competitiveness Of Polish Companies And The Perspective Of Poland Joining The Euro Zone. Society and Economy, 36(1), 95117.

9. European Commission. (2003). Commission Recommendation of 6 May 2003 Concerning The Definition Of Micro, Small And Medium-Sized Enterprises. European Commission.

10. European Commission. (2017). My Region, My Europe, Our Future. Seventh Report On Economic, Social And Territorial Cohesion. Brussels: European Commission.

11. Gabriela, A., \& Delia, G. (2015). The Effect Of Structural Funds On Regional Competitiveness In The New EU Countries: The Case Of Romania And Bulgaria. Annals of 'Constantin Brancusi' University of Targu-Jiu. Economy Series, 1(1), 225-235. 
12. Kleynhans, E. (2016). Factors Determining Industrial Competitiveness And The Role Of Spillovers. Journal of Applied Business Research, 32(2), 527-540.

13. Maciulis, A., Vasiliauskas, A., \& Jakubauskas, G. (2009). The impact Of Transport On The Competitiveness Of National Economy. TRANSPORT, 24(2), 93-99.

14. Martinez, F., \& Potluka, O. (2015). Does the EU Funding Increase Competitiveness of Firms by Supporting Organisational Changes? Journal of Competitiveness, 7(2), 23-37.

15. Maskell, P. , \& Malmberg, A. (1999). Localised Learning And Industrial Competitiveness. Cambridge Journal of Economics, 23(2), 167-185.

16. Remeikiene, R., \& Gaspareniene, L. (2016). Evaluation Of The Impact Of The EU Structural Support On The Competitiveness Of Lithuanian Economics. Central European Journal of Public Policy, 10(1), 1-11.

17. Tijanic, L., \& Obadic, A. (2015). Can We Boost The Competitiveness Of The European Union Through Reducing Regional Inequalities In Human Capital? Engineering Economics, 25(3), 295-305.

18. Travkina, I., \& Tvaronaviciene, M. (2011). Export competitiveness And Domestic Productivity Facets: Case of Lithuania. Journal of Business Economics and Management, 12(1), 49-68. 